\section{AB0287 DECREASE IN 14-3-3ETA PROTEIN LEVELS IS CORRELATED WITH IMPROVEMENT OF CLINICAL DISEASE ACTIVITY IN TOFACITINIB TREATED EARLY RHEUMATOID ARTHRITIS PATIENTS}

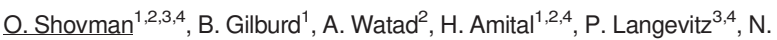
L. Bragazzi ${ }^{5}$, M. Adawi ${ }^{6}$, D. Pérez ${ }^{1}$, M. Blank ${ }^{1,4}$, N.K. Biln ${ }^{7}$, A. Marotta ${ }^{7}$, Y. Shoenfeld ${ }^{1,4,8}$. ${ }^{1}$ Zabludowitz Center for Autoimmune Diseases; ${ }^{2}$ Department of Internal Medicine ' $B$ '; ${ }^{3}$ Rheumatology Unit, Sheba Medical Center, Ramat Gan; ${ }^{4}$ Sackler Faculty of Medicine, Tel Aviv University, Tel Aviv, Israel; ${ }^{5}$ School of Public Health, Department of Health Sciences (DISSAL), University of Genoa, Genoa, Italy, ${ }^{6}$ Padeh and Ziv hospitals, Bar-llan Faculty of Medicine, Zefat, Israel, ${ }^{7}$ Augurex Life Sciences Corp, Vancouver BC, Canada; ${ }^{8}$ Incumbent of the Laura SchwarzKipp Chair for Research of Autoimmune Diseases, Tel Aviv University, Tel Aviv, Israel

Background: $14-3-3 \eta$ protein is a proinflammatory mediator that may represent a novel diagnostic and prognostic biomarker for rheumatoid arthritis (RA). Objectives: To assess the disease activity parameters and $14-3-3 \eta$ protein concentrations in serum of early RA patients treated with Tofacitinib.

Methods: Paired serum samples from 35 previously non-treated early RA patients (disease onset less than 1 year) receiving Tofacitinib were obtained at baseline and 5 months after the initiation of treatment. Levels of $14-3-3 \eta$ were

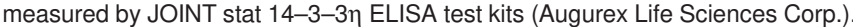
The cut-off was defined as $0.19 \mathrm{ng} / \mathrm{ml}$. We investigated the correlation between changes in serum 14-3-37 concentrations and changes in clinical disease activity index (CDAI), simplified disease activity index (SDAI), Disease Activity Score (DAS) 4CRP and DAS4ESR

Results: Increased concentrations of $14-3-3 \eta$ were found in $57 \%$ of the patients at baseline and in $37 \%$ of the patients after 5 months of treatment. Mean \pm SD baseline $14-3-3 \eta$ concentrations $[4.92 \pm 8.86 \mathrm{ng} / \mathrm{ml}]$ were significantly higher $(p=0.005)$ than those found following treatment $[1.97 \pm 4.59 \mathrm{ng} / \mathrm{ml}]$. Statistically significant improvement $(p<0.001)$ of CDAI, SDAI, DAS4ESR and DAS4CRP was achieved after the 5 month of treatment. No correlation was found between absolute $14-3-3 \eta$ concentrations and parameters of clinical disease activity at both time points. Decrease in $14-3-3 \eta$ protein levels were highly correlated with improvement in DAS4ESR $(r=0.50, p<0.01)$ and moderately correlated with improvement in CDAI ( $r=0.32)$, SDAI ( $r=0.33)$, and DAS4CRP $(r=0.46, p<0.01)$. Conclusions: The study demonstrates that decrease in 14-3-3n protein concentrations in RA patients treated with Tofacitinib is correlated with improvement of clinical disease activity parameters. $14-3-3 \eta$ protein is a useful biomarker for monitoring Tofacitinib therapy.

Disclosure of Interest: O. Shovman: None declared, B. Gillburd: None declared, A. Watad: None declared, H. Amital: None declared, P. Langevitz: None declared, N. L. Bragazzi: None declared, M. Adawi: None declared, D. Pérez: None declared, M. Blank: None declared, N. K. Biln Employee of: Augurex Life Sciences Corp, A. Marotta Employee of: Augurex Life Sciences Corp, Y. Shoenfeld: None declared

DOI: 10.1136/annrheumdis-2018-eular.1682

\begin{tabular}{|l|l|}
\hline AB0288 & LEVELS OF METALLOPROTEINASE-3 (MMP-3) \\
CORRELATE BETTER WITH CLINICAL DISEASE \\
ACTIVITY INDEX (CDAI) AND SIMPLIFIED DISEASE \\
ACTIVITY INDEX (SDAI) THAN STANDARD DISEASE \\
ASSESSMENT SCORE (DAS-28)
\end{tabular}

O. Vega ${ }^{1}$, Y. Calvo ${ }^{2}$, Z. Torres ${ }^{2}$, R. Gamboa ${ }^{3}$, S. Flores ${ }^{4} .{ }^{1}$ Rheumatology; ${ }^{2}$ Laboratory of Immunology, Clínica Reumacenter, Juliaca; ${ }^{3}$ Service of Rheumatology, Hospital Nacional Guillermo Almenara, Lima; ${ }^{4}$ Nurse Unit, Clínica Reumacenter, Juliaca, Peru

Background: The MMP-3 is a matrixin calcium-dependent zinc-containing; the major expressed in rheumatoid synovial tissue; with essential role in the degradation of both aggrecan and collagen fibrils.

Objectives: The aim was to evaluate the correlation of MMP3 levels with assessment scores of RA activity.

Methods: 109 patients with RA as per the 2010 ACR/EULAR criteria were included in the prospective Study ALTRA. Patients were divided into groups of early arthritis active, established arthritis active, and remission with conventional remissive or biological remissive. The levels of MMP3 and activity scores: DAS28-ERS, DAS28-CPR, SDAI and SDAl were on the basis of predefined cutoffs. The correlation was determined with the Pearson Test for parametric variables and the Spearman Test for non-parametric variables.

Results: The levels of MMP3 in patients with early RA Vs established were 63.2 and $39.9 \mathrm{U} / \mathrm{ml}, \mathrm{p}<0.021$ respectively.

MMP3 levels of patients with activity measured by DAS28-ESR were 62.9 in the active and $35.2 \mathrm{U} / \mathrm{ml}$ in remission, $p<0.000$.
The correlation between serum levels of MMP3 and DAS28-ERS was 0.21 $(p<0.25)$, with DAS28-CRP $0.27(p<0.004)$; CDAI $0.26(p<0.06)$ and with SDAI $0.35(\mathrm{p}<0.002)$.

Conclusions: Elevated MMP3 levels indicate state of disease activity; besides the addition in the expression of the collagen damage. This finding may help in making decisions in clinical practice.

\section{REFERENCES:}

[1] Ohrndorf S, Fischer IU, Kellner H, Strunk J, Hartung W, Reiche B, et al. Reliability of the novel 7 -joint ultrasound score: results from an inter- and intraobserver study performed by rheumatologists. Arthritis Care Res (Hoboken) 2012;64(8):1238-43.

[2] Houseman M, Potter C, Marshall N, Lakey R, Cawston T, Griffiths I, et al. Baseline serum MMP-3 levels in patients with Rheumatoid Arthritis are still independently predictive of radiographic progression in a longitudinal observational cohort at 8 years follow up. Arthritis Res Ther 2012;14(1): R30.

[3] Moller I, Janta I, Backhaus M, Ohrndorf S, Bong DA, Martinoli C, et al. The 2017 EULAR standardised procedures for ultrasound imaging in rheumatology. Ann Rheum Dis. 2017;76(12):1974-9.

[4] Siddiqui IJ, Luz J, Borg-Stein J, O'Connor K, Bockbrader M, Rainey H, et al. The Current State of Musculoskeletal Ultrasound Education in Physical Medicine and Rehabilitation Residency Programs. PM R. 2016;8(7):660-6.

[5] Willemze A, Toes RE, Huizinga TW, Trouw LA. New biomarkers in rheumatoid arthritis. Neth J Med. 2012;70(9):392-9.

Acknowledgements: Lic. Marcela Tafur

Disclosure of Interest: None declared

DOI: 10.1136/annrheumdis-2018-eular.5289

\section{AB0289 PARAOXONASA 1 ACTIVITY IS MODULATED BY ANTI- RHEUMATIC TREATMENT AND L55M POLYMORPHISM IN PATIENTS WITH RHEUMATOID ARTHRITISFROM SOUTHERN MEXICO}

O. Zaragoza-García ${ }^{1}$, M.E. Moreno-Godínez ${ }^{1}$, I. Parra-Rojas ${ }^{1}$, J.E. NavarroZarza $^{2}$, N. Castro-Alarcón ${ }^{1}$, I.P. Guzmán-Guzmán ${ }^{1}{ }^{1}$ Facultad de Ciencias Químico Biológicas, Universidad Autónoma de Guerrero; ${ }^{2}$ Hospital General, Chilpancingo, Mexico

Background: Paraoxonase-1 (PON-1) is a high-density lipoprotein (HDL)-associated antioxidant enzyme with anti-atherogenic properties. Although genetic polymorphisms are known to modulate PON-1 activity, ${ }^{1}$ other factors as the consumption of disease-modifying anti-rheumatic drugs (DMARDs) and nonsteroidal anti-inflammatory drugs (NSAIDs) can also modulate its function. ${ }^{2}$

Objectives: To analyse the association between PON-1 activity according to L55M polymorphism and anti-rheumatic treatment in patients with rheumatoid arthritis (RA) from southern Mexico.

Methods: Serum PON1 activity, using 4-chlorometyl phenylacetate (4-CMPA) as substrate $^{3}$ was quantified in 246 RA patients (181 treated with DMARDs, NSAIDs and/or corticosteroids, and 65 without treatment). The PON1 rs854560 genotype (L55M) was determined by the PCR-RFLP method.

Results: PON-1 activity was decreased in RA patients under treatment anti-rheumatic. In addition, an effect of LM/MM genotype of L55M polymorphism was noted in treated patients who exhibiting the lowest PON-1 activity $(10.45 \mathrm{vs} 13.91 \mathrm{U} / \mathrm{mL}$, $\mathrm{p}=0.05$ ). The distribution of $\mathrm{L} 55 \mathrm{M}$ genotypes were; $86.8 \%(\mathrm{LL}), 12.8 \%(\mathrm{LM})$ and $0.4 \%$ (MM). The Leflunamide and diclofenac drugs were associated with the mainly decrease of the PON-1 activity $(\mathrm{p}<0.05)$, compared with others DMARDs, NSAIDs and corticosteroids drugs used to RA in pharmacological regimens. Conclusions: PON-1 activity is impaired in association with the anti-rheumatic treatment and L55M polymorphism, so in patients with RA the susceptible background genetic could contribute to increasing the cardiovascular risk linked to PON-1 activity.

\section{REFERENCES :}

[1] Leviev I, Deakin S, James RW. Decreased stability of the M54 isoform of paraoxonase as a contributory factors to variations in human serum paraoxonase concentrations. J Lipid Res. 2001;42:528-535.

[2] Dilek E, Polat MF. In vitro inhibition of three different drugs used in rheumatoid arthritis treatment on human serum paraoxanase 1 enzyme activity. Protein Pept Lett. 2016;23(1):3-8.

[3] Richter RJ, Jarvik GP, Furlong CE. Determination of paraoxonase 1 status without the use of toxic organophosphate substrates. Cir Cardiovasc Genet. 2008;1:147-152.

Disclosure of Interest: None declared DOI: 10.1136/annrheumdis-2018-eular.5941 